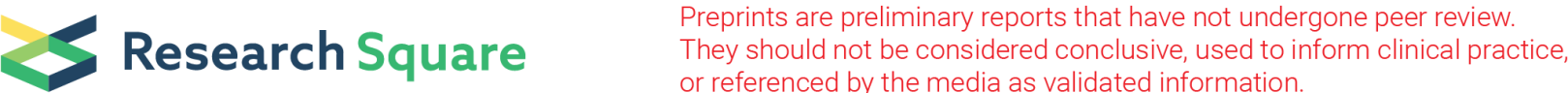

\section{The effect of Wogonoside on the expression of pulmonary fibrosis factor in Mycoplasma pneumoniae pneumonia}

\section{Huihui Wang}

Heilongjiang Academy of Chinese Medicies Sciences

\section{Xiaoxi Wang}

Heilongjiang Academy of Chinese Medicine Sciences

\section{Zhimin Yang}

Heilongjiang Academy of Chinese Medicine Sciences

Huixing Xu

Heilongjiang Academy of Chinese Medicine Sciences

\section{Xin Wang}

Heilongjiang Acedemy of Chinese Medicine Sciences

\section{Guixin Tang}

Harbin Institute of Technology

\section{Yanli Meng}

Heilongjiang Academy of Chinese Medicine Sciences

\section{Weiming Wang ( $\nabla$ wangweiming475@yahoo.com )}

Southern Medical University https://orcid.org/0000-0003-3837-1993

\section{Research}

Keywords: Wogonoside, Mycoplasma pneumoniae pneumonia, TGF- $\beta 1$, Surface plasmon resonance, UPLC-Q-TOF-MS

Posted Date: June 4th, 2020

DOl: https://doi.org/10.21203/rs.3.rs-32122/v1

License: (c) (i) This work is licensed under a Creative Commons Attribution 4.0 International License. Read Full License 


\section{Abstract \\ BACKGROUND}

Mycoplasma pneumoniae pneumonia (MPP) is an acute respiratory infectious pneumonia with pulmonary interstitial fibrosis. TGF- $\beta 1$ is well accepted as the central mediator for fibrosis which promotes the formation of tissue fibrosis factor. Qinbaiqingfei pellet (Qinbai) has already been approved as the first effective new traditional Chinese medicine which can delay activities of Mycoplasma pneumoniae (M.pneumoniae) and protect lung epithelial cells in clinical trials. However, the mechanism of Qinbai inhibiting the expression of TGF- $\beta 1$ is still unclear.

\section{METHODS}

The Chinese herbs in Qinbai were screened by surface plasmon resonance (SPR) and it was deteimined that Scutellaria baicalensis extracts in Qinbai showed the best binding with TGF- $\beta 1$. Then the active ingredient whicn can be bound with TGF- $\beta 1$ protein in the solution of Qinbai and Scutellaria baicalensis was isolated and analyzed by UPLC-Q-TOF-MS, which proved the active ingredient was Wogonoside. The affinity constant of Wogonoside and TGF- $\beta 1$ protein was measured by SPR affinity analysis. A549 cells infected with M.pneumoniae were intervened by Wogonoside, and then the expression of TGF- $\beta 1$ and Smad3 in A549 cells were analyzed by PCR and western blotting.

\section{RESULTS}

The results showed the bound effect of Scutellaria baicalensis and TGF- $\beta 1$ was effective. The active ingredients which can be bound with TGF- $\beta 1$ in the solution of Scutellaria baicalensis and Qinbai were obtained and analyzed to investigate the mechanism of Qinbai inhibiting the expression of TGF- $\beta 1$. UPLC-Q-TOF-MS results showed that the active ingredients was Wogonoside. SPR affinity analysis showed that the affinity constant was $21.71 \mu \mathrm{M}$. Pharmacological experiments revealed that Wogonoside strongly inhibited the expression of TGF- $\beta 1$ and Smad3 in A549 cells infected by M.pneumoniae.

\section{CONCLUSION}

Wogonoside in Qinbai can be bound with TGF- $\beta 1$ and down-regulate the expression of lung fibrosis factors TGF- $\beta 1$ and Smad3. The finding may improve our understanding the molecular mechanism of Qinbai mediating MPP and provide new sights into the future pharmacological investigation of Qinbai.

\section{Background}

Mycoplasma pneumoniae (M.pneumoniae), a gram-stained negative microorganism, is a major cause for respiratory tract infections and community-acquired pneumonia ${ }^{[1]}$, accounting for approximately 
$10 \%-30 \%$ of all cases and as much as to $50 \%$ in outbreak years ${ }^{[2]}$. M.pneumoniae is spherical or silk without cell wall, which makes it instinctually resistant to antimicrobials, such as $\beta$-lactams ${ }^{[3]}$, azithromycin and glucocorticoid ${ }^{[4]}$. M.pneumoniae could attach to epithelial members, produce reactive oxygen species and injure epithelial cells. Mycoplasma pneumoniae pneumonia (MPP) is an acute respiratory infectious pneumonia with pulmonary interstitial fibrosis. M.pneumoniae invades the bronchioles, connective tissue around the bronchi and the alveolar septum, and eventually leads to interstitial fibrosis. Due to lung hypoplasia in children, M.pneumoniae is prone to cause interstitial fibrosis after repeated infections ${ }^{[5]}$. TGF- $\beta 1$ is well accepted as the central mediator for fibrosis ${ }^{[6]}$. It promotes the formation of tissue fibrosis factor in the aspect of strongest expression, increases in fibrosis diseases, promotes fibrosis foci inflammatory cells and fibroblast aggregation ${ }^{[7,8]}$

Qinbaiqingfei pellet (Qinbai) has already been approved as the first effective new traditional Chinese medicine which can delay activities of M.pneumoniae and protect lung epithelial cells in clinical trials. The previous studies have shown Qinbai can inhibit the expression of M.pneumoniae adhesion proteins $\mathrm{P} 1$ and P30 and promote the repair of airway tissues and epithelial cells ${ }^{[9-11]}$. Yao et al. pointed that Qinbai inhibited epithelial-mesenchymal transition (EMT) of alveolar type $₫$ epithelial cells by reducing the content of TGF- $\beta$ and restore the normal morphology and function of the lung by increasing the expression of SP-A ${ }^{[12]}$. Wang et al. found that Qinbai decreased the expression of cytokines Wnt5a and aSMA, and inhibit the cellulose deposition after MPP ${ }^{[13]}$.

The traditional Chinese medicine Scutellaria baicalensis, the dry root of Scutellaria baicalensis Georgi, is the most important herb in Qinbai. Scutellaria baicalensis has been used for the treatment of "Lung-Heat" syndrome in China for a long time. In Xiaochaihu Decoction and Chaigejieji Decoction which are the classical prescriptions for the treatment of pulmonary infectious diseases and initially recorded in Han Dynasty (20-220 AD), Scutellaria baicalensis is the main herb ${ }^{[14]}$. In the traditional Chinese medicine practice, there have reported several researches on the pulmonary inflammation treatment by Scutellaria baicalensis $^{[15-17]}$. Xu et al. ${ }^{[14]}$ pointed that Scutellaria baicalensis may inhibit excessive release of proinflammatory cytokines, thereby inhibiting the systemic inflammatory response syndrome and promoting lung repair of tissue inflammatory lesions. Scutellaria baicalensis can suppress different tissue and organ fibrosis occurrence and development via various mechanisms, including down-regulating expression of promote-fibrosis cytokines, inhibiting pro-fibrogenic signaling pathways, anti-inflammatory and anti-oxidant effects ${ }^{[19-21]}$. It's confirmed that the active components of Scutellaria baicalensis are Wogonoside, Baicalin, Baicalein and Wogonin ${ }^{[22,23]}$. Wogonoside is a flavonoid ingredient with various biological activities, such as anti-tumor, anti-inflammatory and anti-oxidation ${ }^{[24-26]}$. Previous studies showed that Wogonoside inhibited the TLR4 expression and the phosphorylation of NF-kappa B p65 and I kappa B induced by LPS, exerting anti-inflammatory effects ${ }^{[23,27]}$. However, there are few reports on the treatment of MPP with Wogonoside and the mechanism of Wogonoside inhibiting the deposition of pulmonary interstitial cellulose to treat MPP needs to be further studied. 
The surface plasmon resonance (SPR) biosensor is a refractometer that measures changes in the optical reflectivity of a thin metal film when species adsorb or bind to its surface or to any material coated onto its surface ${ }^{[18,28]}$. SPR has been applied in numerous fields including the researches of Chinese herbal medicine targets, medical diagnostics and pharmaceutical analysis ${ }^{[29]}$. Based on SPR, Cao et al. firstly discovered that physcion-8-O- $\beta$-D-monoglucoside was a bioactive ingredient and the affinity to TNF-R1 was $376 \mathrm{nM}^{[30]}$. Tu et al. confirmed that protocatechualdehyde could control cardiovascular remodeling by binding with collagen $\mathrm{I}^{[13]}$. In present study, it was found that Scutellaria baicalensis extract in Qinbai showed the best binding with TGF- $\beta 1$. On this foundation, SPR was applied to identify the active ingredient in Scutellaria baicalensis and reveal the mechanism of Qinbai in the treatment of MPP.

\section{Materials And Methods}

\section{Materials}

A549 cells were kindly provided by Chinese Academy of Sciences Stem Cell Bank (China). Mycoplasma pneumonia was purchased from DAAN GENE (China). RPMI 1640 medium and fetal bovine serum (FBS) were obtained from Hyclone (USA). PPLO broth was purchased from BD Biosciences (USA). Fresh yeast was purchased from Angel Yeast Company (China). Human TGF- $\beta 1$ protein was purchased from ACROBiosystems (USA). SDS-PAGE Gel Kit was obtained from Solarbio life sciences (China). Amine Couping Kit (BR-1000-50), Acetate 4.0 and $\mathrm{NaOH}(50 \mathrm{mM}$ ) were purchased from GE Healthcare (Sweden). Mouse anti-TGF- $\beta 1$ antibody (ab64715) and Rabbit anti-Smad3 (ab40854) antibody were purchased from Abcam (USA). Rabbit anti- $\beta$-actin (bs-0061R) was purchased from Bioss (UK). Peroxidase-Conjugated Goat anti-Mouse IgG $(\mathrm{H}+\mathrm{L})$ and Peroxidase-Conjugated Goat anti-Rabbit Ig $(\mathrm{H}+\mathrm{L})$ were purchased from ZSGB-BIO (China). Trizol reagent was purchased from Life Technologies (USA). Go Taq 1-Step RT-qPCR System was purchased from Promega (USA). RIPA reagent was provided by Beyotime (China). Bradford method kit was purchased from Nanjing Jiancheng Biotechnology Co.Ltd (China). Polyvinylidene difluoride (PVDF) membranes were purchased from Biosharp (China). Hypersensitive electrochemiluminescene kit was obtained from Wanleibio (China). Scutellaria baicalensis was purchased from Beijing Tongrentng Pharmacy (China). Qinbai (Batch number: 130701) was obtained from Harbin tianheli Pharmaceutical Co., Ltd. Wogonoside was purchased from Shanghai Yuanye Biotechnology Co.Ltd, (20 mg, B20488, HPLC>98\%). Formic acid was purchased from Fisher Scientific (USA). Methanol and acetonitrile were respectively purchased from Kermel (China) and Merck (Germany). ACQUITYTM UPLC system was obtained from Waters (USA). Triple-TOFTM $5600^{+}$mass spectrometer was obtained from AB SCIEX (USA). Acquity UPLC BEH C 18 column $(2.1 \mathrm{~mm} \times 100 \mathrm{~mm}, 1.7 \mu \mathrm{M})$ and AQUITY UPLC BEH $\mathrm{C}_{18}$ VanGuard Pre-Column $(2.1 \mathrm{~mm} \times 5 \mathrm{~mm}, 1.7 \mu \mathrm{M})$ were purchased from Waters (USA). Fluorescent Quantitative Detection System (Line Gene 9600) was purchased from BIOER (China). Biacore T200 was purchased from GE Healthcare (Sweden). Gel imaging system (Versa Doc MP 4000) was obtained from BIO-RAD (USA). 


\section{Preparation of six herbal extracts of Qinbai}

Qinbai is composed of six Chinese herbal medicines including Scutellaria baicalensis, Platycodon grandiflorus, Pheretima aspergillum, Stemona japonica, Aster tataricus and Ophiopogon japonicus. According to Chinese Pharmacopoeia (2015 Edition), the six herbal extracts were prepared as follows:

Scutellaria baicalensis extract: $84 \mathrm{~g}$ Scutellaria baicalensis was extracted with water for $4 \mathrm{~h}$. The filtrate was concentrated to the relative density of $1.05-1.10\left(80^{\circ} \mathrm{C}\right)$, and $\mathrm{pH}$ was adjusted to 1.0-2.0 with 2 $\mathrm{mol} / \mathrm{L} \mathrm{HCl}$ at $80^{\circ} \mathrm{C}$. The solution was allowed to stand for $24 \mathrm{~h}$. The supernatant was washed with water to $\mathrm{pH} 5.0$, and then washed with $70 \%$ ethanol until $\mathrm{pH}$ reached 7.0. Finally, the solution was pulverized into fine powder at low temperature.

Pheretima aspergillum extract: $63 \mathrm{~g}$ Pheretima aspergillum was crushed properly and extracted twice with $70 \%$ ethanol solution, the first time for 2 hours, the second time for 1.5 hours. After filtration, the filtrate was combined. Platycodon grandiflorus extract: $42 \mathrm{~g}$ Platycodon grandiflorum was decocted twice with water for $1.5 \mathrm{~h}$ each time, and the filtrate was filtered and combined. At $60^{\circ} \mathrm{C}$, the filtrate was concentrated into a transparent paste with a relative density of 1.30-1.35.

The extracts of Stemona japonica, Aster tataricus and Ophiopogon japonicus were prepared according to the extraction process of Platycodon grandiflorus.

\section{SDS-PAGE}

TGF- $\beta 1$ protein solution was diluted from $200 \mu \mathrm{g} / \mathrm{mL}$ to $160 \mu \mathrm{g} / \mathrm{mL}$ with the loading buffer and then heated at $100{ }^{\circ} \mathrm{C}$ for $5 \mathrm{~min}$. SDS-PAGE was carried out with $12 \%$ polyacrylamide gel according to the molecular weight of TGF- $\beta 1$. The experimental conditions were as follows: the loading volume of TGF- $\beta 1$ protein was $5 \mu \mathrm{L}$, the concentrated gel voltage was $70 \mathrm{~V}$ for $30 \mathrm{~min}$ and the separated gel voltage was $110 \mathrm{~V}$ for $1 \mathrm{~h}$. The protein band was stained with Coomassie brilliant blue for $1 \mathrm{~h}$ and then eluted until the background was completely clean. The photograph was taken by the gel imaging system.

\section{The binding of Scutellaria baicalensis and other herbal extracts with TGF- $\beta 1$ by SPR technology}

SPR analysis was performed on the Biacore T200 system. Prior to the analysis, the whole flow path was primed by phosphate buffer saline (PBS) for three times and 70\% bianormalizing solution was used for signal normalization. The CM5 sensor chip was activated by injecting the mixture of $100 \mathrm{mM} \mathrm{N}$ hydroxysuccinimide and $400 \mathrm{mM}$ N-ethyl-N'-(diethylaminopropyl)-carbodiimide (BR-1000-50, Uppsala, Sweden). The solution of TGF- $\beta 1$ protein was diluted in the $\mathrm{pH} 4.0$ sodium acetate to $6 \mu \mathrm{g} / \mathrm{mL}$ and immobilized on the second channel of the CM5 sensor chip for $600 \mathrm{~s}$ at a flow rate of $10 \mu \mathrm{L} / \mathrm{min}$. Finally, the CM5 sensor chip was blocked with ethanolamine. The first channel served as a negative control. The 
extract of Scutellaria baicalensis and other herbal extracts were dissolved into $20 \mathrm{mg} / \mathrm{mL}$ solution with PBS solution respectively.

Every herbal extract was injected to TGF- $\beta 1$ sensor surface for $60 \mathrm{~s}$ at a flow rate of $30 \mu \mathrm{L} / \mathrm{min}$ and then the chip surface was regenerated by glycine hydrochloric acid solution with $\mathrm{pH} 2.0$ for 30 s. The sensorgram was recorded and expressed in resonance units (RU).

\section{Recovery of TGF- $\beta 1$ bound ingredients}

TGF- $\beta 1$ protein was coupled to four channels of another CM 5 chip with the final concentration of 6 $\mu \mathrm{g} / \mathrm{mL}$. Similarly, $20 \mathrm{mg} / \mathrm{mL}$ Scutellaria baicalensis extract was injected into the chip surface at a flow rate of $5 \mu \mathrm{L} / \mathrm{min}$ for $180 \mathrm{~s}$. The system was then washed with PBS to thoroughly remove the remaining sample solution. Then a small volume of $2 \mu \mathrm{L}$ recovery solution $(0.5 \% \mathrm{HCOOH})$ was injected into the flow cells and incubated for 20 s to allow the bound ingredient to be dissociated into the recovery solution. The flow direction over the sensor surface was reversed and the recovery solution containing TGF- $\beta 1$ bound ingredients was deposited in $10 \mu \mathrm{L}$ ammonium bicarbonate $(50 \mathrm{mM})$. In order to obtain sufficient samples, the total number of cycles was set to $20.20 \mathrm{mg} / \mathrm{mL}$ Qinbai solution was also processed and recovered as the procedures above.

\section{UPLC-QTOF/MS analysis}

The SPR-recovered samples were dried under nitrogen and dissolved in $100 \mu \mathrm{L}$ methanol. The analysis of the SPR-recovered samples was performed on Waters ACQUITYTM UPLC system. The chromatographic columns were a Waters ACQUITY UPLC BEH $\mathrm{C}_{18}$ column $(2.1 \times 100 \mathrm{~mm}, 1.7 \mu \mathrm{M})$ and a Van Guard PreColumn $(2.1 \mathrm{~mm} \times 5 \mathrm{~mm}, 1.7 \mu \mathrm{M})$. The mobile phase consisted of $0.1 \%$ aqueous formic acid $(\mathrm{A})-0.1 \%$ formic acid acetonitrile (B), using a gradient elution. The flow rate was $0.4 \mathrm{~mL} / \mathrm{min}$ and the injection volume was $10 \mu \mathrm{L}$. Elution procedure is $5 \%-100 \% \mathrm{~B}$ at $0-13 \mathrm{~min}, 100 \%-5 \% \mathrm{~B}$ at $13-13.10 \mathrm{~min}$ and $5 \% \mathrm{~B}$ at 13.10-15.00 min for SPR recovered samples. Mass spectrometry detection was performed by the $A B$ SCEIX Triple-TOFTM 5600 ${ }^{+}$high resolution mass spectrometer. The product ion scan range was 50-1500 $\mathrm{Da}$, enabling dynamic background deduction. The condition of ESI source was as follows: ion source voltage, $5500 \mathrm{~V}$ ( positive ion mode), $4500 \mathrm{~V}$ (negative ion mode); ion source temperature, $550{ }^{\circ} \mathrm{C}$; atomizing gas, $\mathrm{N}_{2}$; auxiliary gas pressure, $379.17 \mathrm{kPa}$; air curtain gas pressure, $241.99 \mathrm{kPa}$; fragmentor voltage, $80 \mathrm{~V}$; collision energy, $\pm 35 \mathrm{eV}$; collision energy expansion, $15 \mathrm{eV}$. IDA was set to respond to the 8 highest peaks of more than $100 \mathrm{cps}$ for secondary mass spectrometry scanning. All data was obtained by Analyst TF 1.6 software and analyzed by Peakview 2.0/masterview 1.0 software.

\section{SPR affinity analysis}


The system was primed by $10 \%$ methanol before experiments. Wogonoside was diluted in $10 \%$ methanol to 5 gradient concentrations $(280 \mathrm{nM} / \mathrm{mL}$ to $17.5 \mathrm{nM} / \mathrm{mL})$, then injected through the reference and active channels for $60 \mathrm{~s}$ at the rate of $30 \mu \mathrm{L} / \mathrm{min}$, and regenerated with $\mathrm{pH} 2.0$ Glycine-HCL for $60 \mathrm{~s}$. The experiments of $70 \mathrm{nM} / \mathrm{mL}$ were performed twice to assess the repeatability. The total number of cycles was 3. Finally, the results were analyzed by Biacore evaluation software (T200 Version 1.0) and fitted a steady-state affinity model to obtain the affinity constant $\left(K_{D}\right)$. Equilibrium dissociation constant $\left(K_{D}\right)$ was derived by fitting to a 1:1 Langmuir bound model.

\section{M.pneumoniae and cell culture}

The M.pneumoniae cells (ATCC 15531) were cultured in PPLO broth (containing $20 \%$ fetal bovine serum, $10 \%$ yeast extract solution, $1 \%$ glucose, and $0.0002 \%$ phenol red), incubated at $37^{\circ} \mathrm{C}$ with $5 \% \mathrm{CO}_{2}$ and subcultured every 7 days. A549 cells were maintained in RPMI 1640 medium with $10 \%$ FBS at $37{ }^{\circ} \mathrm{C}$ and $5 \% \mathrm{CO}_{2}$, and subcultured every 3 days. $1 \times 10^{5} \mathrm{~A} 549$ cells were divided into infected cell group (infected by $10^{6} \mathrm{CCU}$ M.pneumoniae for $4 \mathrm{~h}$ ), Wogonoside group (infected and given $40 \mu \mathrm{M}$ Wogonoside for 3 days) and blank group.

\section{Real-time quantitative PCR}

Total RNAs were extracted from A549 cells by Trizol. The level of RNAs was amplified by one-step Reverse Transcription-PCR kit and determined by Bioer Technology (China). The ratio for mRNA of interest was normalized to $\beta$-actin and presented as the mean \pm SD.

The primers used are as follows:

TGF- $\beta 1$ forward primer: 5'-AGC AAC AAT TCC TGG CGA TAC CTC-3'

TGF- $\beta 1$ reverse primer: 5'-TCA ACC ACT GCC GCA CAA CTC-3'

Smad3 forward primer: 5'-CAC AGC ATG GAC GCA GGT TCT C-3'

Smad3 reverse primer: 5'-AGG AGA TGG AGC ACC AGA AGG C-3'

$\beta$-actin forward primer: 5'-ACA GAG CCT CGC CTT TGC-3'

$\beta$-actin reverse primer: 5'-GCG GCG ATA TCA TCA TCC-3'

\section{Western blotting}

A549 cells were lysed by RIPA extraction reagent and then centrifuged $\left(4^{\circ} \mathrm{C}\right)$ for $10 \mathrm{~min}$ at the rate of $12000 \mathrm{rpm} / \mathrm{min}$. Total protein concentration was determined by the Bradford assay method. Samples 
were subjected to $12 \%$ SDS-PAGE and then transferred to PVDF membranes. The membranes were blocked with $5 \%$ non-fat dry milk in TBST (200 mM Tris buffer, $\mathrm{pH} 8.0$, containing $150 \mathrm{mM} \mathrm{NaCl}$ and $0.1 \%$ Tween 20) at room temperature for $1 \mathrm{~h}$. The membranes were incubated with primary antibodies overnight at $4{ }^{\circ} \mathrm{C}$. After incubated with HRP-conjuated anti-rabbit lgG or anti-mouse secondary antibodies, protein bands were visualized using enhanced chemiluminescence (ECL) substrate by Versa Doc Imaging Analysis System and quantified by densitometry using the Image $\mathrm{J}$ software.

\section{Statistical analysis}

All experiments were repeated at least twice. Data were presented as mean $\pm S D$ and analyzed statistically with Dunnett's test. Differences were considered significant at $P<0.05$.

\section{Results}

\section{SDS-PAGE}

As shown in Fig.1, TGF- $\beta 1$ protein showed a clear band in the molecular weight range of $48 \mathrm{kDa}$ and 35 $\mathrm{kDa}$, which was in accordance with the experimental standard.

\section{The bound results of Scutellaria baicalensis and other herbal extracts with TGF- $\beta 1$ by SPR analysis}

According to Fig.2, TGF- $\beta 1$ protein solution diluted in $\mathrm{pH} 4.0$ sodium acetate showed the best bound effect and the bound value reached 8894.9 RU. According to the results in Fig.3, the binding value of Scutellaria baicalensis extract to TGF- $\beta 1$ protein was significantly higher than that of other five herbs.

The results in Fig. 4 showed that the bound curve of the second channel gradually increased and was higher than the first channel. The bound value of the 2-1 channel reached 159.2 RU in the steady state, indicating that the Scutellaria baicalensis extract showed a good binding with the target protein in vitro.

\section{Recognition and recovery of the TGF- $\beta 1$ bound ingredients}

TGF- $\beta 1$ protein solution was connected to four channels of CM 5 chip for fishing ligand. The bound values in Fig. 5 were 8192.9 RU, 6679.6 RU, 7687.1 RU, 5939.9 RU, indicating the protein was successfully bound with $\mathrm{CM} 5$ chip. Wogonoside was indentified as a recovery ingredient based on the retention time and $\mathrm{m} / \mathrm{z}$ information in both positive and negative modes (Fig.6, Fig.7, Fig.8 and Table 1). The negative mode was employed as it showed better sensitivity of ion response than the positive mode. Fig.6A and Fig.7A showed that the fragmental ions of Wogonoside at $\mathrm{m} / \mathrm{z} 285\left[\mathrm{M}+\mathrm{H}-\mathrm{C}_{6} \mathrm{H}_{8} \mathrm{O}_{6}\right]^{+}$and $\mathrm{m} / \mathrm{z} 270[\mathrm{M}+\mathrm{H}-$ 
$\left.\mathrm{C}_{6} \mathrm{H}_{8} \mathrm{O}_{6}-\mathrm{CH}_{3}\right]^{+}$were detected in the positive mode. In the negative mode (Fig.6B and Fig.7B), the fragment ion was $\mathrm{m} / \mathrm{z} 283$ due to loss of $176\left(\mathrm{C}_{6} \mathrm{H}_{8} \mathrm{O}_{6}\right)$ and $\mathrm{m} / \mathrm{z} 268$ was from the loss of $15\left(\mathrm{CH}_{3}\right)$. The retention time of Wogonoside was consistent with recovered ingredients and the error were less than $10 \mathrm{ppm}$.

Table 1

UPLC-Q-TOF-MS data in both positive and negative ion mode of Wogonoside and recovered samples.

\begin{tabular}{|c|c|c|c|c|c|c|c|}
\hline Name & Formula & $\begin{array}{l}\text { Mass } \\
\text { (Da) }\end{array}$ & $\begin{array}{l}\text { Extraction } \\
\text { Mass (Da) }\end{array}$ & $\begin{array}{l}\text { Error } \\
\text { (ppm) }\end{array}$ & $\begin{array}{l}\text { Main ion } \\
\text { mass } \\
\text { peaks } \\
(\mathrm{m} / \mathrm{z})\end{array}$ & 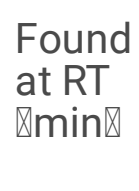 & Adduct \\
\hline \multirow[t]{6}{*}{ Wogonoside } & \multirow[t]{16}{*}{$\mathrm{C}_{22} \mathrm{H}_{20} \mathrm{O}_{11}$} & \multirow[t]{16}{*}{460.10056} & \multirow[t]{3}{*}{460.10784} & \multirow[t]{3}{*}{0.7} & 461.1044 & \multirow[t]{3}{*}{6.422} & \multirow[t]{3}{*}{$+\mathrm{H}$} \\
\hline & & & & & 285.0722 & & \\
\hline & & & & & 270.0494 & & \\
\hline & & & \multirow[t]{3}{*}{459.09329} & \multirow[t]{3}{*}{7.3} & 283.7638 & \multirow[t]{3}{*}{5.684} & \multirow[t]{3}{*}{$-H$} \\
\hline & & & & & 268.0377 & & \\
\hline & & & & & 163.0029 & & \\
\hline \multirow{5}{*}{$\begin{array}{l}\text { Scutellaria } \\
\text { baicalensis } \\
\text { extracts }\end{array}$} & & & \multirow[t]{2}{*}{461.10784} & \multirow[t]{2}{*}{0.6} & 285.0764 & \multirow[t]{2}{*}{6.420} & \multirow[t]{2}{*}{$+\mathrm{H}$} \\
\hline & & & & & 270.0531 & & \\
\hline & & & \multirow[t]{3}{*}{459.09631} & \multirow[t]{3}{*}{3} & 283.0622 & \multirow[t]{3}{*}{5.689} & \multirow[t]{3}{*}{$-H$} \\
\hline & & & & & 268.0368 & & \\
\hline & & & & & 163.0024 & & \\
\hline \multirow[t]{5}{*}{ Qinbai solution } & & & \multirow[t]{2}{*}{461.10784} & \multirow[t]{2}{*}{0.8} & 285.0765 & \multirow[t]{2}{*}{6.231} & \multirow[t]{2}{*}{$+\mathrm{H}$} \\
\hline & & & & & 270.0528 & & \\
\hline & & & \multirow[t]{3}{*}{459.09329} & \multirow[t]{3}{*}{2.4} & 283.0612 & \multirow[t]{3}{*}{5.517} & \multirow[t]{3}{*}{$-H$} \\
\hline & & & & & 268.0380 & & \\
\hline & & & & & 165.9895 & & \\
\hline
\end{tabular}

\section{The bound results of Wogonoside with TGF- $\beta 1$ protein by SPR analysis}

SPR assay was conducted to verify the direct interaction of Wogonoside with TGF- $\beta 1$ protein. As shown in Fig.9A, serial concentrations of Wogonoside ranging from $17.5 \mathrm{nM} / \mathrm{mL}$ to $280 \mathrm{nM} / \mathrm{mL}$ were injected and bound with TGF- $\beta 1$ protein. It was found that the binding value increased gradually with the increase of the concentration. SPR analysis revealed that the dissociation constant $\left(K_{D}\right)$ was calculated as 21.71 


\section{The decreased expression of TGF- $\beta 1$ and Smad 3 in M.pneumoniae infected A549 cells by Wogonoside}

As shown in Fig.10, the mRNA levels of TGF- $\beta 1$ and Smad3 in the M.pneumoniae group were higher than those of the blank group $(P<0.01)$. Meanwhile, it was found that the downregulation of TGF- $\beta 1$ and Smad3 was observed after treated with $40 \mu \mathrm{M}$ Wogonoside. Western blotting analysis (Fig.11) revealed that Wogonoside could decrease the protein expression of TGF- $\beta 1(P<0.01)$ and Smad3 $(P<0.05)$. In conclusion, the experimental results indicated that Wogonoside could reduce the expression of TGF- $\beta 1$ and Smad3, thereby inhibiting the activity of M.pneumoniae.

\section{Discussion}

As we all know, it's a very difficult process to find the active ingredients from complex herbal medicines. SPR biosensors have become an important tool for characterizing and quantifying biomolecular interactions. In addition, considerable progress has been made in the development of SPR sensors for detecting chemical and biological species. Based on the SPR technology, the six herbal extracts of Qinbai were bound with TGF- $\beta 1$ protein respectively, and then the active ingredients which could be bound with TGF- $\beta 1$ protein were screened preliminarily. Nevertheless, SPR does not provide information for structural identification of protein-bound ingredients in an unknown mixture. UPLC-Q-TOF-MS was adopted to analyze the active ingredients. In this study, we described a method for screening the active ingredient from Chinese herbal medicines by SPR biosensor and UPLC-Q-TOF-MS technology.

The result showed that the bound value of Scutellaria baicalensis extract with TGF- $\beta 1$ protein reached 2881.9 RU, which was significantly higher than the other five herbs in Qinbai. The result laid a foundation for the study of the effective components of Qinbai. The bound result of Scutellaria baicalensis extract and TGF- $\beta 1$ protein (Fig. 4) showed that the bound value gradually increased with the prolongation of injection time and was significantly higher than that of the reference channel. In addition, the difference of bound values at stable state reaches 159.2RU, indicating certain binding of Scutellaria baicalensis extract with TGF- $\beta 1$ protein. UPLC-Q-TOF-MS results showed that the molecular formula, retention time, and fragmentation information of active ingredients that could be bound with TGF- $\beta 1$ in the solution of Scutellaria baicalensis and Qinbai were consistent with those of Wogonoside standard, indicating that Wogonoside in Scutellaria baicalensis is one of the major active ingredients in Qinbai. The affinity of Wogonoside and TGF- $\beta 1$ protein was determined based on SPR technology. 1: 1 bound model of small molecules and proteins was used for kinetic analysis. The affinity constant range of small molecules and proteins was $10^{-6} \mathrm{M} \otimes 10^{-3} \mathrm{M}$. The bound values of Wogonoside with TGF- $\beta 1$ at different concentrations in Fig. 9B showed that the $\mathrm{K}_{\mathrm{D}}$ was $21.71 \mu \mathrm{M}$ which was consistent with the affinity characteristics of 
small molecules and proteins, indicating that there is a specific binding between Wogonoside and TGF$\beta 1$.

Respiratory mucosal epithelial cells are particularly susceptible to pathogens. Repairing damaged respiratory mucosal epithelium is very important for the treatment of MPP. Therefore, A549 cells were selected for this study. M.pneumoniae stain assay was used to evaluate the cells with the infection of M.pneumoniae. It has been demonstrated that $10^{6} \mathrm{CCU}$ M.pneumoniae could lead to the presence of cloud-like stains around $A 549$ cells $^{[31]}$. The result suggested that M.pneumoniae had been successfully adhered to $\mathrm{A} 549$ cells. In present study, $10^{6} \mathrm{CCU}$ M.pneumoniae was selected to build M.pneumoniae models.

The former studies indicated that A549 cells were obviously inhibited after the treatment with different doses of Wogonoside. The half-inhibitory concentration $\left(\mathrm{IC}_{50}\right)$ value was identified to be $46.1 \mu \mathrm{M}^{[32]}$. Wogonoside of $40 \mu \mathrm{M}$ was selected in this study to detect the ability to inhibit the expression of TGF- $\beta 1$ and Smad3 after M.pneumoniae infection. Previous studies revealed that the effects of TGF- $\beta$ are performed by the activation of downstream Smads, including Smad3 and Smad4 ${ }^{[33]}$. In addition, Smad3 mediated TGF- $\beta 1$-augmented contraction in HFL- 1 cells ${ }^{[34]}$. In present study, the results of PCR and Western blotting showed that $40 \mu \mathrm{M}$ Wogonoside markedly inhibited the impression of TGF- $\beta 1$ and Smad3 in M.pneumoniae models.

\section{Conclusion}

In conclusion, the present study indicated Wogonoside in Qinbai can be bound with TGF- $\beta 1$ and downregulate the expression of lung fibrosis factors TGF- $\beta 1$ and Smad3. The finding may improve our understanding the molecular mechanism of Qinbai mediating MPP and provide new sights into the future pharmacological investigation of Qinbai.

\section{Abbreviations}

MPP: Mycoplasma pneumoniae pneumonia; Qinbai:Qinbaiqingfei pellet; M.pneumoniae:Mycoplasma pneumoniae, SPR:surface plasmon resonance.

\section{Declarations}

\section{Acknowledgements}

We thank Professor Wang Wenfei of Northeast Agricultural University for his guidance on the experiment technology.

\section{Authors' contribution}


All the authors have contributed significantly. Huihui Wang for Conceptualization, data curation and writing-original draft. Yanli Meng and Weiming Wang for conceptualization, supervision and writingreview and editing. Guixin Tang and Xin Wang for methodology and resources. Xiaoxi Wang and Huixing $\mathrm{Xu}$ for the formal analysis and validation. Zhimin Yang for software. All authors have read and agreed to the published version of the manuscript.

\section{Funding}

This work was supported by the National Natural Science Foundation of China for Young Scientists (81603367) and National Natural Science Foundation of China (81374045).

\section{Availability of data and materials}

All data generated or analysed during this study are included in this published article.

\section{Ethics approval and consent to participate}

Not applicable.

\section{Consent for publication}

Not applicable.

\section{Competing interests}

The authors declare that they have no competing interests

\section{References}

1. Eldred, J. A. , Hodgkinson, L. M. , Dawes, L. J. , Reddan, J. R. , Edwards, D. R. , and Wormstone, I. M.. MMP2 Activity is Critical for TGF 32 -Induced Matrix Contraction-Implications for Fibrosis. Invest. Ophth. Vis. Sci. 2012; 53(7), 4085-4098. doi:10.1167/iovs.12-9457.

2. Waites, K. B., and Talkington, D. F. Mycoplasma pneumoniae and its role as a human pathogen. Clin. Microbiol. Rev.2014; 17(4), 697-728. doi:10.1128/CMR.17.4.697-728.2004.

3. Saraya, T. The history of mycoplasma pneumoniae pneumonia. Front. Microbiol.2016; 7(662), 364364. doi:10.3389/fmicb.2016.00364.

4. Du X., Ma H., Yang W. Level of matrix metalloproteinase-9 in the serum of patients with idiopathic pulmonary fibrosis and its clinical significance. Clin. Med. Chin. 2005; 21(2): 111-112. doi:10.3760/cma.j.issn.1008-6315.2005.02.008.

5. Gardiner, S. J. , Gavranich, J. B. , and Chang, A. B. Antibiotics for community-acquired lower respiratory tract infections secondary to mycoplasma pneumoniae in children. Cochrane. Db. Syst. Rev. 2015; 1(7): 1-16. doi:10.1002/14651858.CD004875.pub5. 
6. Zhang, Y., Wang, S., Liu, S., Li, C., and Wang, J. Role of Smad signaling in kidney disease. Int. Urol. Nephrol. 2015; 47(12), 1965-1975. doi:10.1007/s11255-015-1115-9.

7. Edwards, D. R., Murphy, G., Reynolds, J. J., Whitham, S. E., Docherty, A. J., Angel, P., and Heath, J. K. Transforming growth factor beta modulates the expression of collagenase and metalloproteinase inhibitor. Embo. J. 1987; 6(7), 1899-1904. doi:10.1002/j.1460-2075.1987.tb02449.x

8. Gauldie, J., Jordana, M., and Cox, G. Cytokines and pulmonary fibrosis. Thorax. 1993; 48(9), 931-935. doi:10.1159/000109195.

9. Meng Y. Wang W., Lv D., An Q., Lu W., Wang X., Tang G. The effect of Platycodin D on the expression of cytoadherence proteins P1 and P30 in Mycoplasma pneumoniae models. Environ Toxicol Pharmacol. 2017; 49, 188-193. doi: 10.1016/j.etap.2017.01.001

10. Meng Y., Huo J., Lu W., Wang X., Zhang J., Wang W. Modulation of P1 and EGF expression by baicalin. Int J Mol Sci. 2012; 14(1), 146-57. doi: 10.3390/ijms14010146.

11. Meng Y., Yang Y., Lu W., Wang Y., Qian F., Wang X., Zhang Z., Wang W. The inhibition of platycodin D on Mycoplasma pneumoniae proliferation and its effect on promoting cell growth after antiMycoplasma pneumoniae treatment. Front Cell Infect Microbiol. 2015; 4(12), 192. doi: 4:192. 10.3389/fcimb.2014.00192

12. Yao, L., Zhang, J., Wang, B., Sui, M., and Wang, W. Effect of Qinbai Qingfei Concentrated pellets on TGF-ßand SP-A expression in lung tissue of rats infected by mycoplasmal pneumonia. Chinese Pharmacological Bulletin. 2016; 32(4), 564-568. doi: 10.3969/j.issn.1001-1978.2016.04.024.

13. Wan, Y. J., Guo, Q., Liu, D., Jiang, Y., Zeng, K. W., and Tu, P. F. Protocatechualdehyde reduces myocardial fibrosis by directly targeting conformational dynamics of collagen. Eur. J. Pharmacol. 2019; 855, 183-191. doi:1016/j.ejphar.2019.05.003.

14. Xu H., Li Y., Wang C., Liu G., Liu C., Zhang L., Li Q., Li M., Cao H., Cheng M., Wang H. Effect of Scutellariae \adix on expression of inflammatory cytokine protein and gene in lung of mice with viral pneumonia caused by influenza virus FM1 infection.China Journal of Chinese Materia Medica. 2019; 44(23), 5166-5173. doi:10.19540/j.cnki.cjcmm.201910.09.401.

15. Meng Y., Xu J., Wang X., Xu H., Wang X., Cai X., Wang W. The effect of the Baicalin Inhibiting Mycoplasma Pneumoniae. Chinese Archives of Traditional Chinese Medicine. 2019; 37(12), 16731687. doi: 10.13193 /j.issn.1673-7717.2019.12.001.

16. Wang F., Sun Y., Yi W., Fan K., Duan Z., Sun N., Li H., (2018). Effects of matrine combined with baicalin on mouse pneumonia induced by LPS. Chinese Pharmacological Bulletin. 2018; 34(8), 11051109. doi: 10.3969/j. issn.1001-197.2018.08.015.

17. Zhao J., Li S., Liu Y., Tu J., Qu L., Shi K. Pharmacodynamic difference of Scutellaria baicalensis pithnodecayed and Scutellaria baicalensis pith-decayed on pneumonia based on antibacterial activity and pathological parameters.Chinese Traditional and Herbal Drugs. 2018; 49(17), 4064-4070. doi: 10.7501/j.issn.0253-2670.2018.17.015.

18. Campbell, C. T., and Kim, G. SPR microscopy and its applications to high-throughput analyses of biomolecular bound events and their kinetics. Biomaterials. 2007; 28(15), 2380-2392. doi: 
10.1016/j.biomaterials.2007.01.047.

19. Gao Y., Lu J., Zhang Y., Chen Y., Gu Z., Jiang X. Baicalein attenuates bleomycin-induced pulmonary fibrosis in rats through inhibition of miR-21. Pulmonary Pharmacology \& Therapeutics. 2013; 26(6), 649-654. doi:10.1016/j.pupt.2013.03.006.

20. Huang X., He Y., Chen Y., Wu P., Gui D. Cai H., Chen A., Dai C., Yao D., Wang L. Baicalin attenuates bleomycin-induced pulmonary fibrosis via adenosine A2a receptor related TGF- $\beta 1$-induced ERK1/2 signaling pathway[J]. BMC Pulmonary Medicine. 2016, 16(1), 132. doi:10.1186/s12890-016-0294-1.

21. Xiao Y., Ye J., Zhou J., Huang J., Liu X., Huang B., Zhou L., Wu B., Zhang G. Baicalin inhibits pressure overload-induced cardiac fibrosis through regulating AMPK/TGF- $\beta /$ Smads signaling pathway[J]. Archives of biochemistry and biophysics. 2018; 640, 37. doi:10.1016/j.abb.2018.01.006.

22. Gong, W. Y., Wu, J. F., Liu, B. J., Zhang, H. Y., Cao, Y. X., Sun, J., and Dong, J. C. Flavonoid components in Scutellaria baicalensis inhibit nicotine-induced proliferation, metastasis and lung cancerassociated inflammation in vitro. Int. J. Oncol. 2014; 44(5), doi:1561-1570. 10.3892/ijo.2014.2320.

23. Li C, Lin G , Zuo Z. Pharmacological effects and pharmacokinetics properties of Radix Scutellariae and its bioactive flavones[J]. Biopharmaceutics \& Drug Disposition. 2011; 32(8), 427-445. doi:10.1002/bdd.771.

24. Chen, Y., Hui, H., Yang, H., Zhao, K., Qin, Y., Gu, C., and Guo, Q. Wogonoside induces cell cycle arrest and differentiation by affecting expression and subcellular localization of PLSCR1 in AML cells. Blood. 2013; 121(18), 3682-3691. doi:10.1182/blood-2012-11-466219.

25. Shi, G. F., Yao, R. X., Wang, G. Y., Wang, Z. J., and Chen, F. W. Liquid Chromatography-Tandem Mass Spectrometry Screening Method for the Detection of Radical-Scavenging Natural Antioxidants from the Whole Scutellariae (Radix, Stem and Leaf). J. Chromatogr. Sci. 2015; 53(7), 1140-1146. doi:10.1093/chromsci/bmu176.

26. Sun, Y., Zhao, Y., Yao, J., Zhao, L., Wu, Z., Wang, Y., and Lu, N. Wogonoside protects against dextran sulfate sodium-induced experimental colitis in mice by inhibiting NF-KB and NLRP3 inflammasome activation. Biochem. Pharmacol. 2015; 94(2), 142-154. doi:10.1016/j.bcp.2015.02.002.

27. Zhang L., Ren Y. Yang C., Guo Y., Zhang X., Hou G., Guo X., Sun N., Liu Y. Wogonoside Ameliorates Lipopolysaccharide-Induced Acute Lung Injury in Mice. Inflammation. 2014; 37(6), 2006-2012. doi:10.1007/s10753-014-9932-z.

28. Homola, J. Present and future of surface plasmon resonance biosensors. Anal. Bioanal. Chem. 2003; 377(3), 528-539. doi: 10.1007/s00216-003-2101-0.

29. Homola, J. Surface plasmon resonance sensors for detection of chemical and biological species. Chem. Rev. 2008; 108(2), 462-493. doi:10.1002/chin.200818275.

30. Cao, Y., Li, Y. H., Lv, D. Y., Chen, X. F., Chen, L. D., Zhu, Z. Y., and Zhang, J. P. Identification of a ligand for tumor necrosis factor receptor from Chinese herbs by combination of surface plasmon resonance biosensor and UPLC-MS. Anal. Bioanal. Chem. 2016; 408(19), 5359-5367. doi: 10.1007/s00216-0169633-6. 
31. Meng, Y. L., Wang, W. M., Lv, D. D., An, Q. X., Lu, W. H., Wang, X., and Tang, G. The effect of Platycodin D on the expression of cytoadherence proteins P1 and P30 in Mycoplasma pneumoniae models. Environ. Toxicol. Phar. 2017; 49, 188-193. doi: 10.1016/j.etap.2017.01.001.

32. Luo, M., Mo, J., Yu, Q., Zhou, S., Ning, R., Zhang, Y., and Cui, J. Wogonoside induces apoptosis in human non-small cell lung cancer A549 cells by promoting mitochondria dysfunction. Biomed. Pharmacother.2018; 106, 593-598. doi: 10.1016/j.biopha.2018.06.077.

33. Derynck, R., and Zhang, Y. E. Smad-dependent and Smad-independent pathways in TGF- $\beta$ family signalling. Nature. 2003; 425(6958), 577. doi: 10.1038/nature02006.

34. Kobayashi, T., Liu, X., Wen, F. Q., Kohyama, T., Shen, L., Wang, X. Q., and Sugiura, H. Smad3 mediates TGF- $\beta 1$-induced collagen gel contraction by human lung fibroblasts. Biochem. Bioph. Res. Co. 2006; 339(1), 290-295. doi: 10.1016/j.bbrc.2005.10.209.

35. Li H., Zhao S., Yuan Z., Wan H., Lei F., Ding Y., XingD., Du L. Comparative study of the effect of baicalin and its natural analogs on neurons with oxygen and glucose deprivation involving innate immune reaction of TLR2/TNFa.[J]. Journal of Biomedicine \& Biotechnology. 2012; 2012(15):267890. doi:10.1155/2012/267890.

\section{Figures}

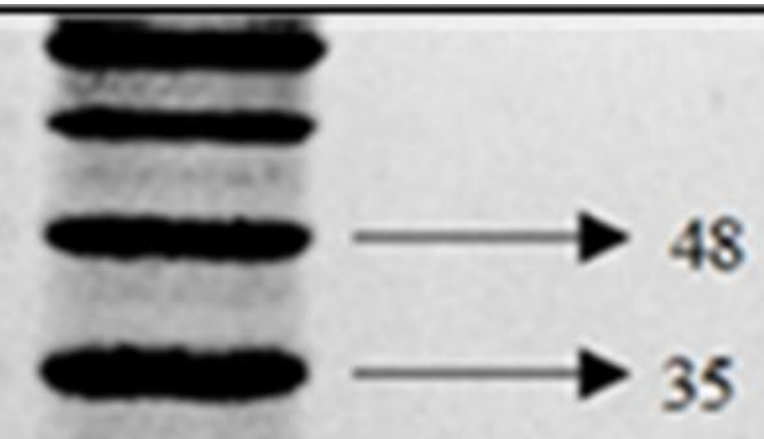


Figure 1

TGF- $\beta 1$ protein purity detected by SDS-PAGE

\section{Chip: CM5}

\begin{tabular}{lllll} 
& & & & Response \\
Flow cell & Procedure & Method & Ligand & Bound (RU) \\
\hline 2 & Time and flow & Amine & TGF-beta & 8894.9
\end{tabular}

Figure 2

The bound result of TGF- $\beta 1$ protein with CM 5 chip 


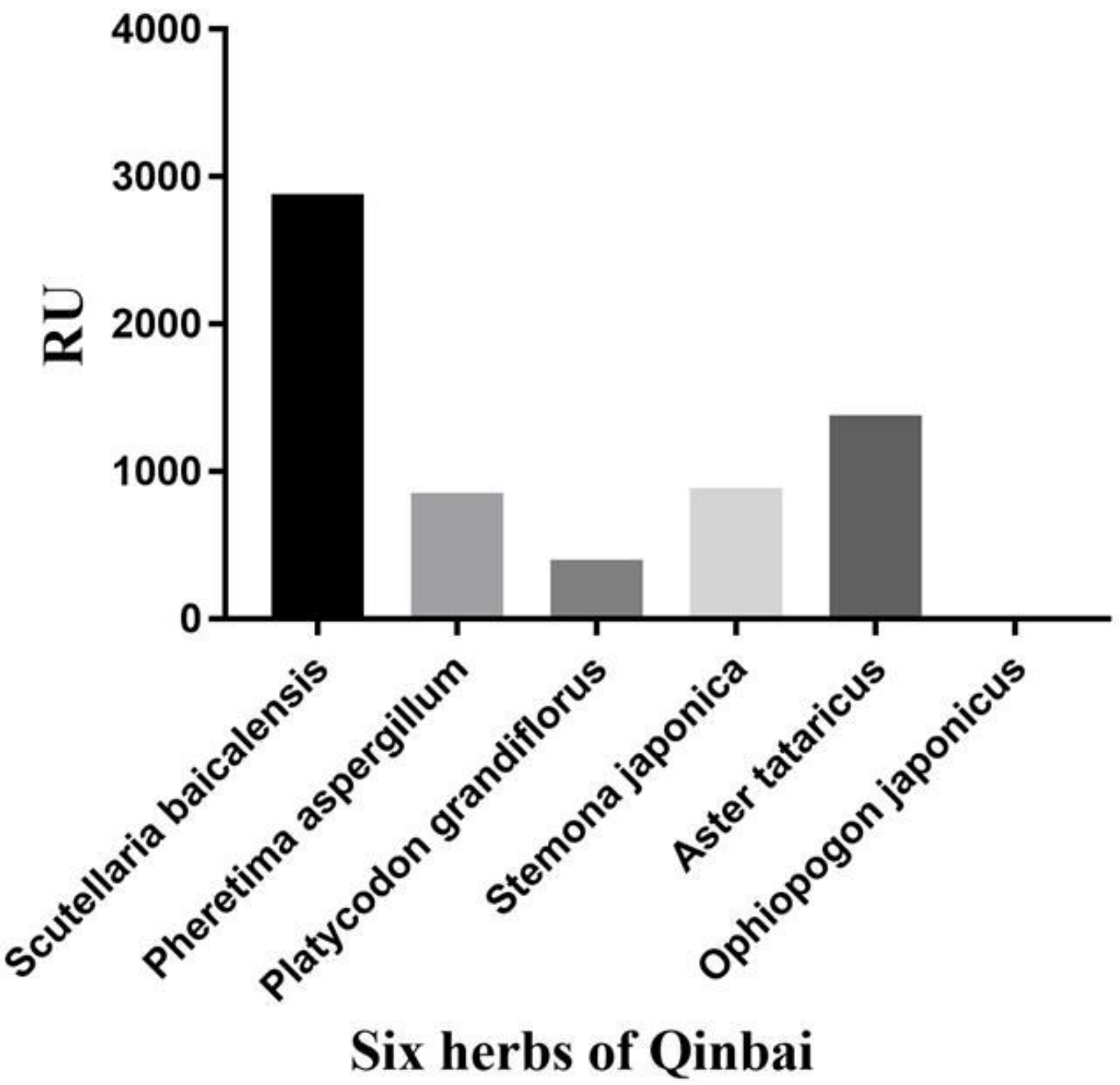

Figure 3

The bound results of six herbal extracts of Qinbai with TGF- $\beta 1$ protein 


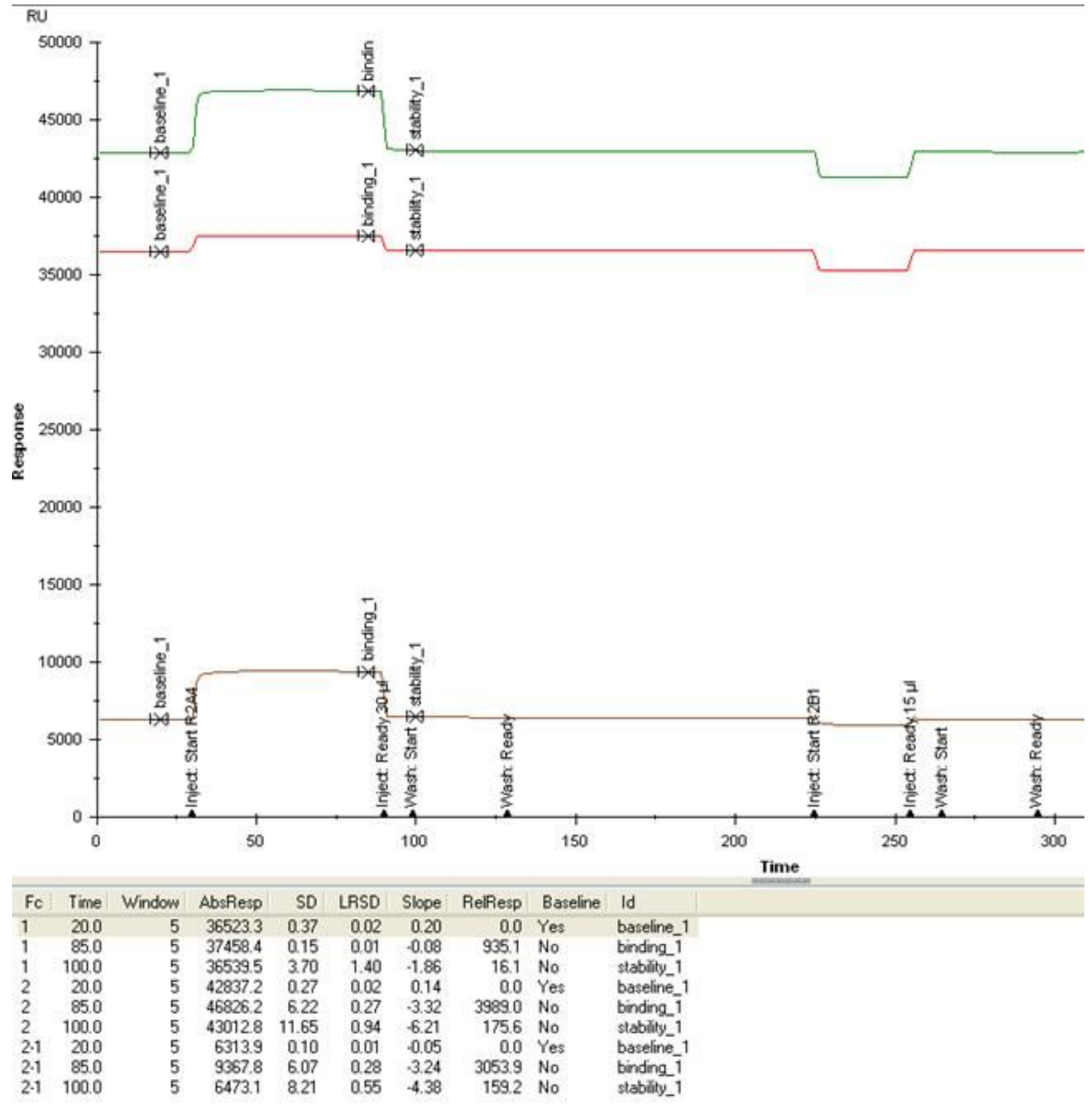

Figure 4

The bound results of Scutellaria baicalensis extract with TGF- $\beta 1$ protein. The green line was the second channel, the red one was the first channel and the brown one was 2-1 channel 


\section{Chip: CM5 \\ Flow cells per cycle: 4}

Flow cell Procedure

1

2

3

4
Time and flow

Time and flow

Time and flow

Time and flow
Method

Amine

Amine

Amine

Amine
Response

Ligand Bound (RU)

$\operatorname{tgf}$

$\operatorname{tgf}$

$\operatorname{tg} f$

$\operatorname{tgf}$
8192.9

6679.6

7687.1

5939.9

Figure 5

The bound results of TGF- $\beta 1$ ligand with four channels of CM5 sensor chip
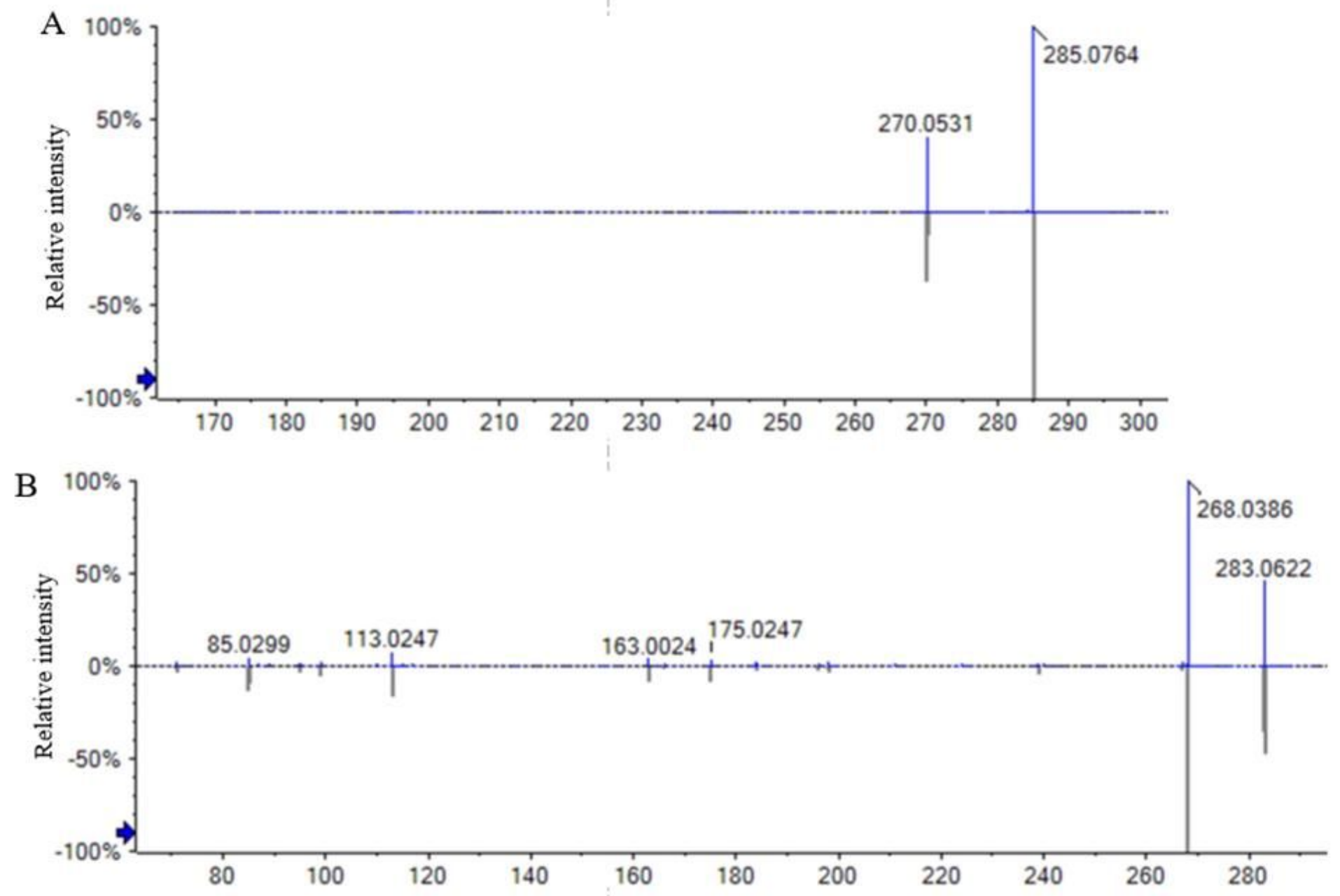

Figure 6 
Secondary fragmentation information of Scutellaria baicalensis extract in positive ion mode $(A)$ and negative ion mode $(B)$.

A

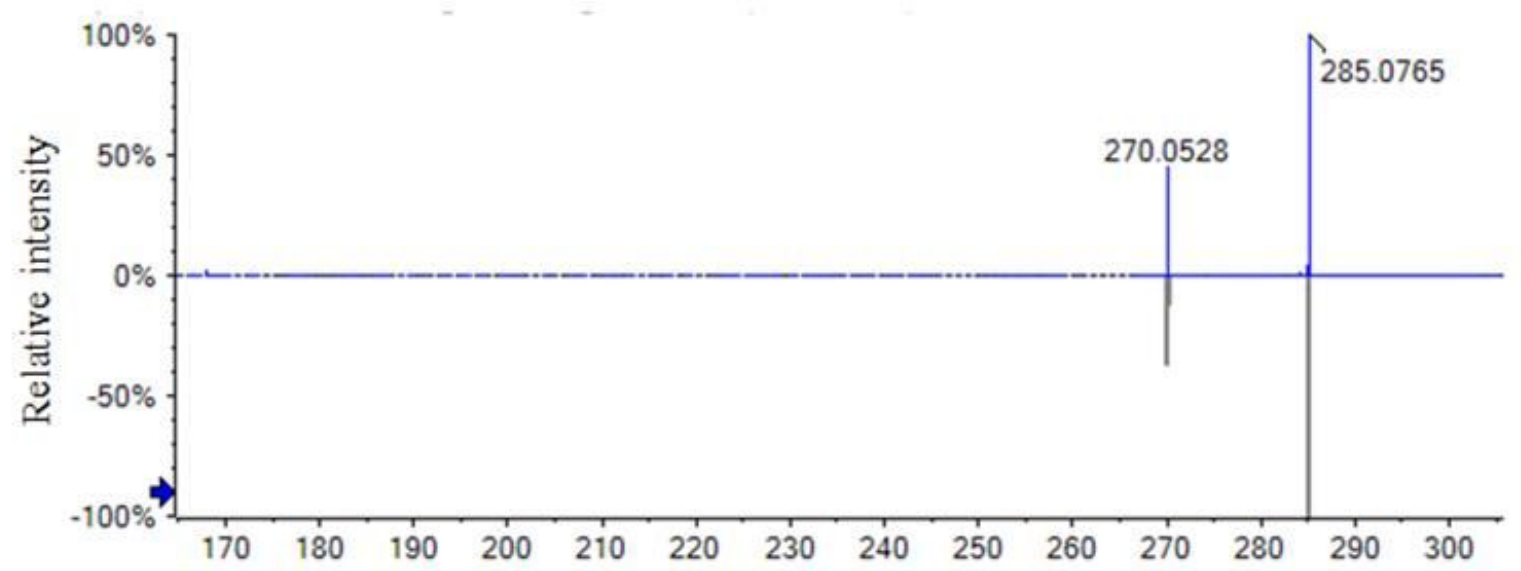

B

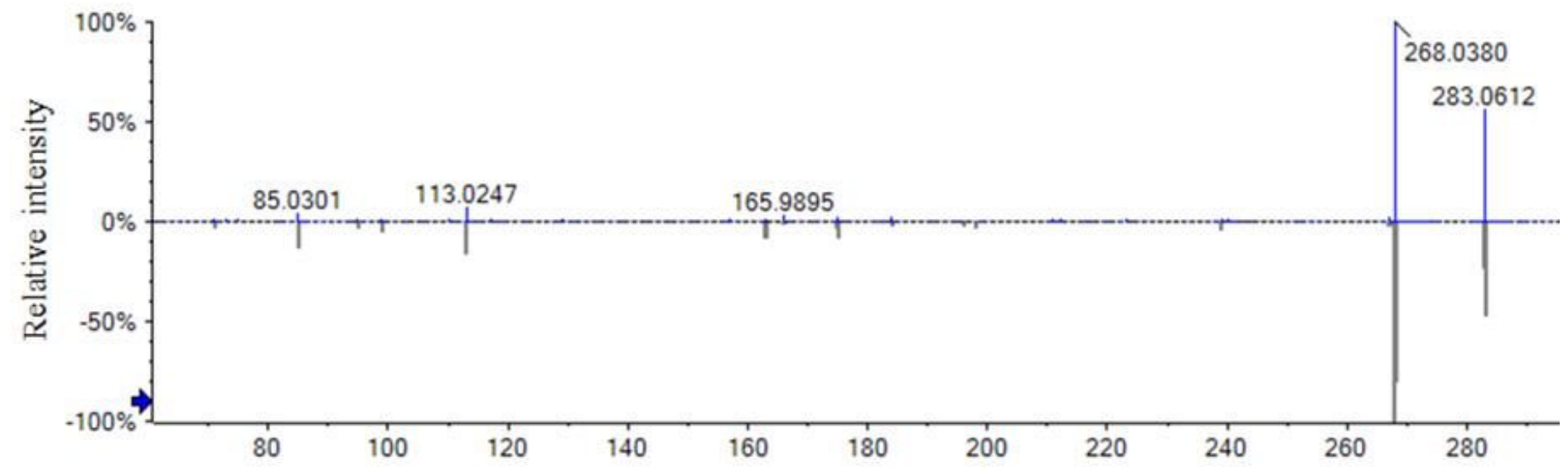

Figure 7

Secondary fragmentation information of Qinbai solution in positive ion mode (A) and negative ion mode (B). 

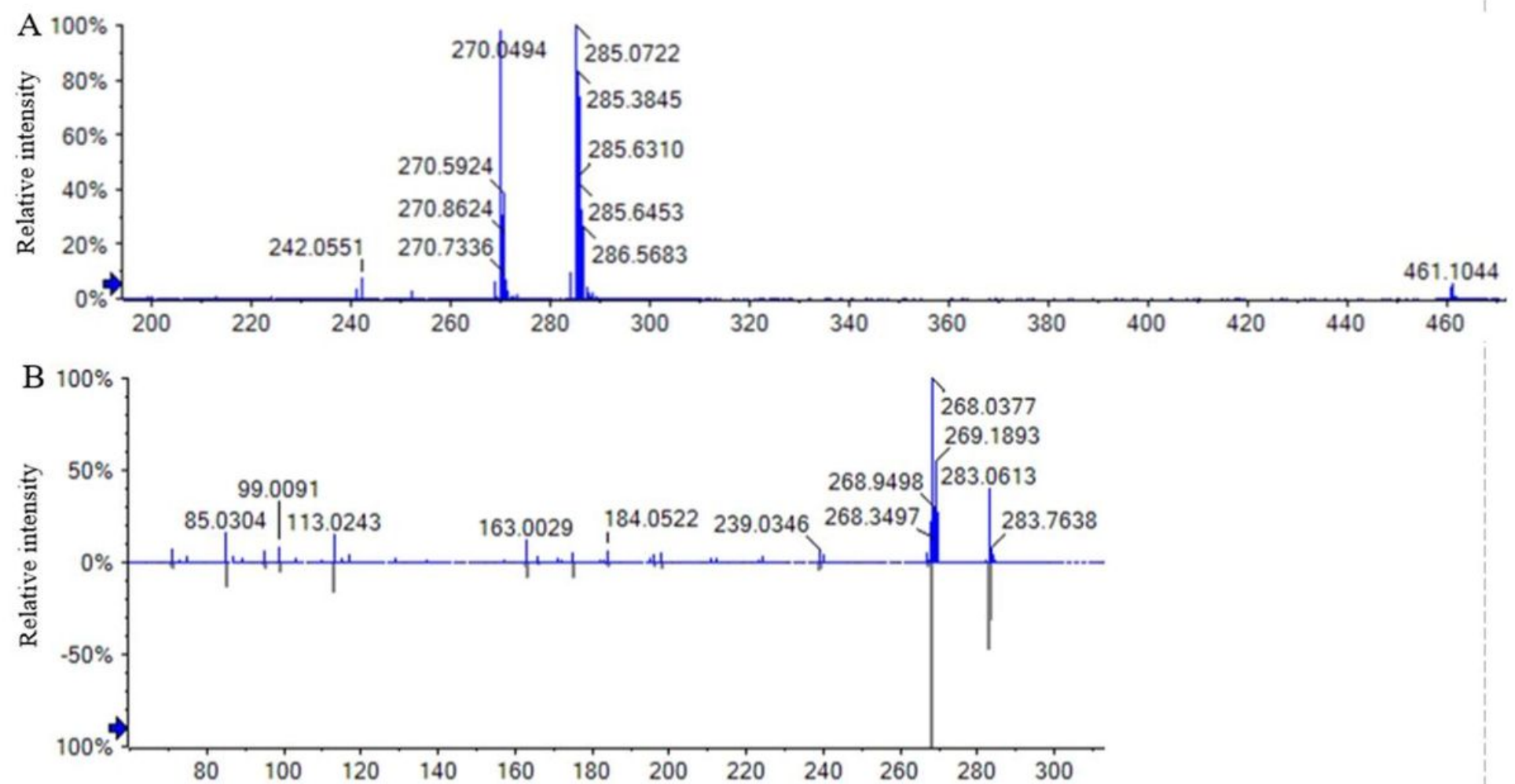

Figure 8

Secondary fragmentation information of Wogonoside in positive ion mode $(A)$ and negative ion mode (B) 

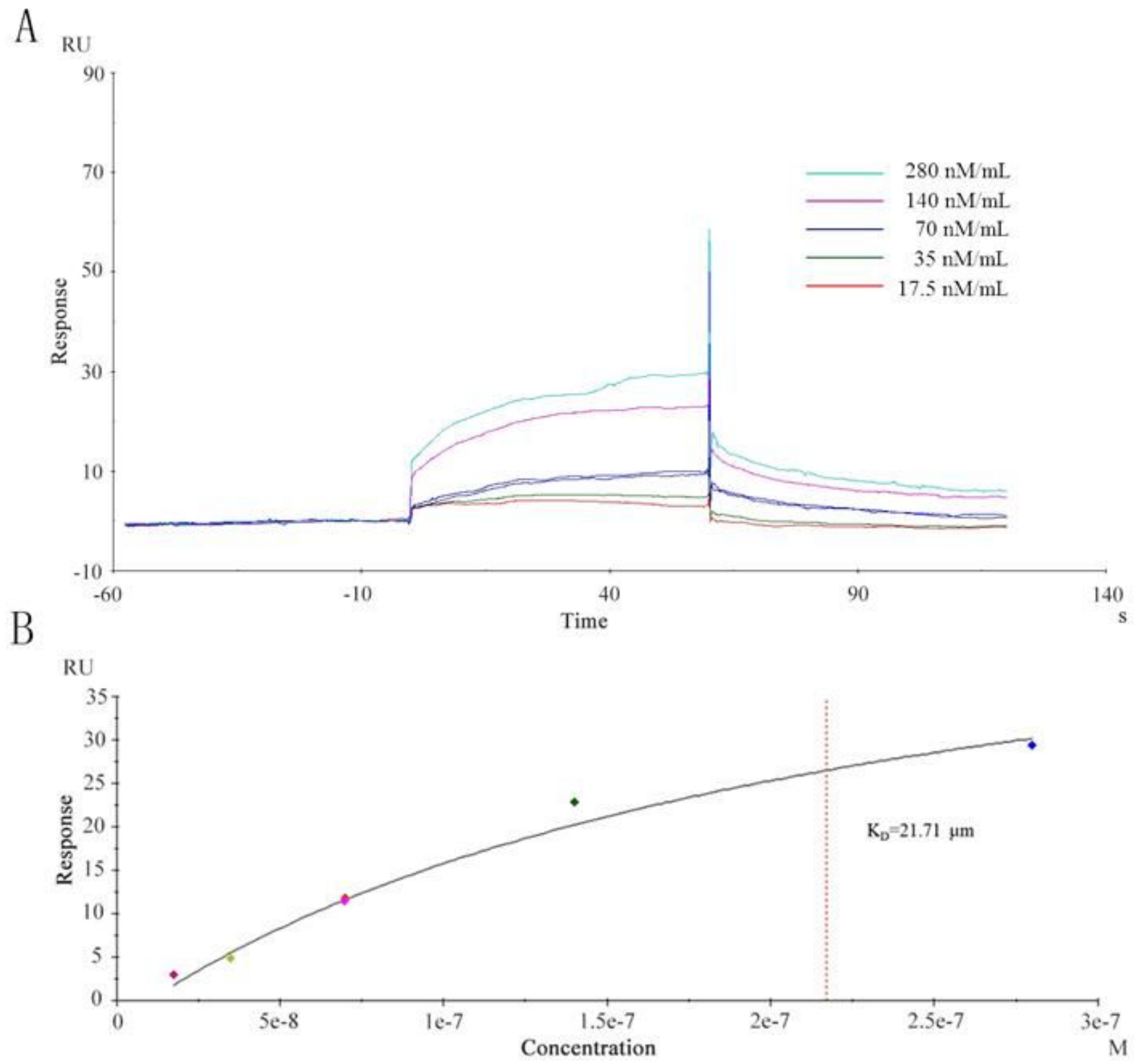

\section{Figure 9}

Measurement of affinity constant by SPR affinity analysis. (A) The bound values of different concentration Wogonoside with TGF- $\beta 1$ protein. (B)The affinity analysis of Wogonoside with TGF- $\beta 1$ protein (KD). 


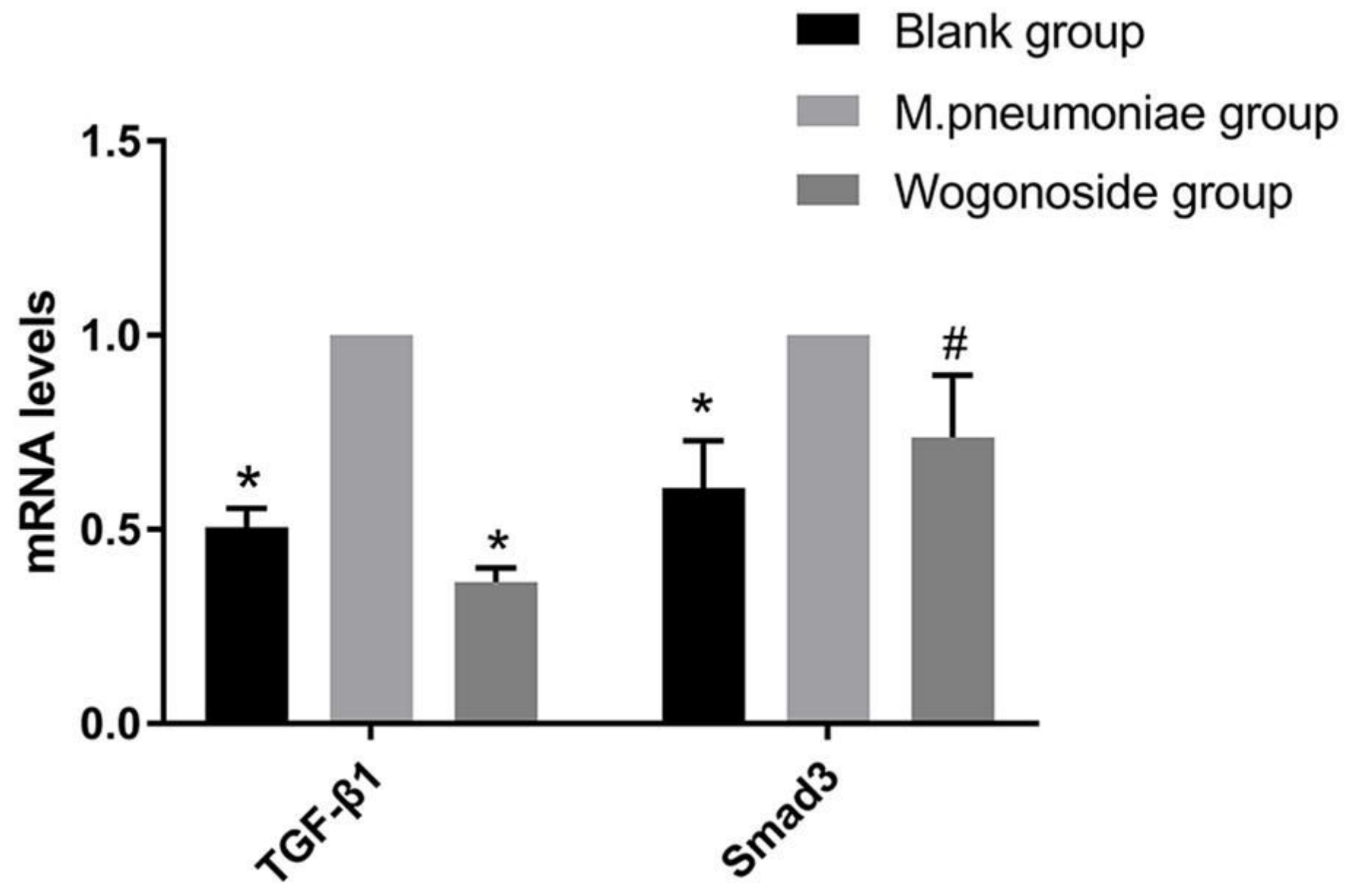

Figure 10

The mRNA levels of TGF- $\beta 1$ and Smad3. RT-PCR analysis of TGF- $\beta 1$ and Smad3 mRNA levels in M.pneumoniae infected A549 cells. Compared with M.pneumoniae group, $* P<0.01, \# P<0.05$. 


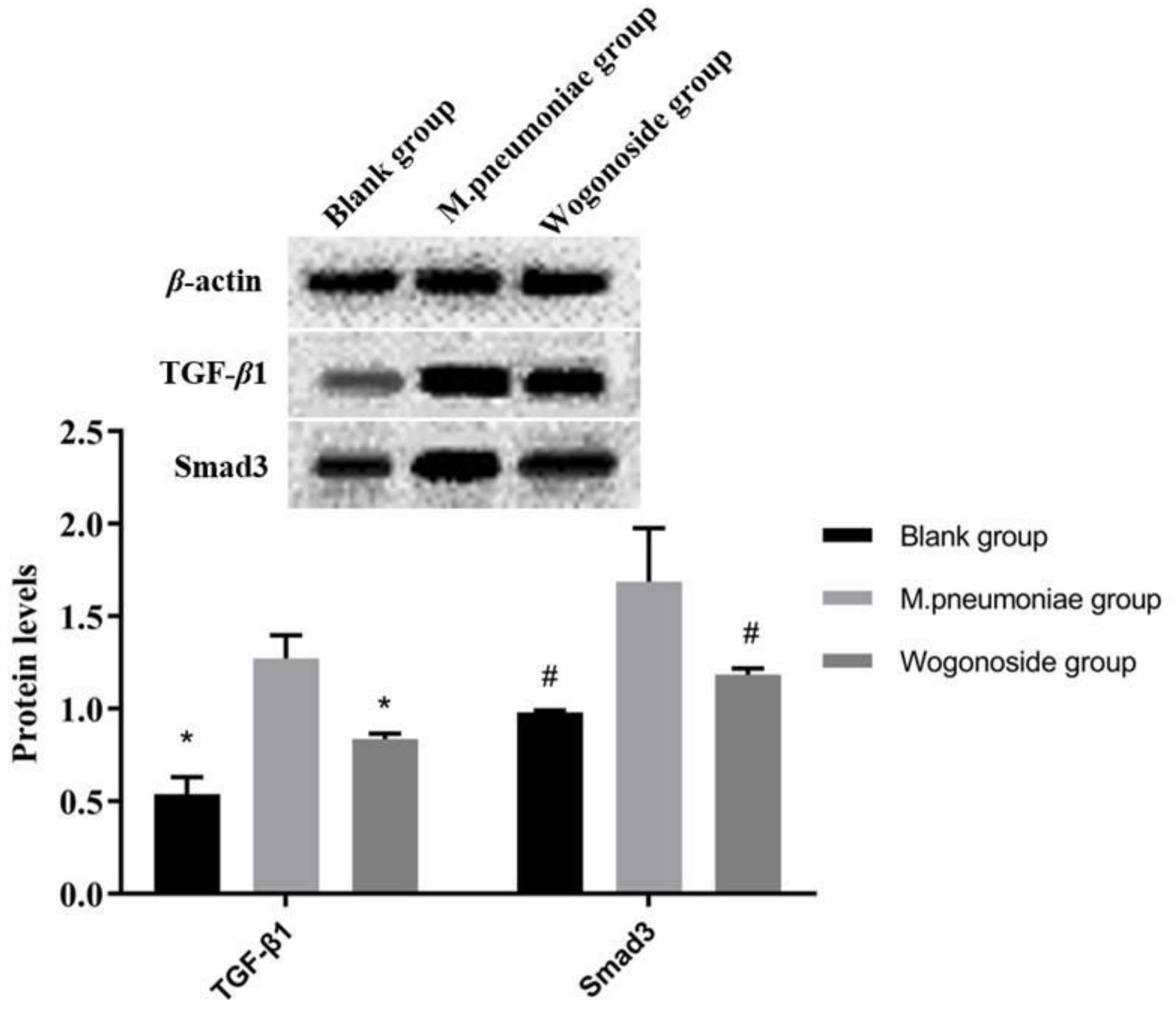

Figure 11

The protein levels of TGF- $\beta 1$ and Smad3. Western blotting analysis of TGF- $\beta 1$ and Smad3 protein levels in M.pneumoniae infected A549 cells. Compared with M.pneumoniae group, ${ }^{*} P<0.01, \# P<0.05$.

\section{Supplementary Files}

This is a list of supplementary files associated with this preprint. Click to download.

- ResearchHighlights.docx

- ResearchHighlights.docx

- ResearchHighlights.docx 